\title{
Ironiens uendelige frihed
}

\section{Ironi i En dansk Students Eventyr}

\section{Poul Møllers forhold til ironi}

"Det undskyldes, at Begyndelsen hentes noget langt borte«, skriver Poul Martin Møller i afhandlingen »Om Begrebet Ironie« fra 1835. ${ }^{1}$ Samme undskyldning kunne gælde for denne artikel. Mit formål er at præsentere en læsning af En dansk Students Eventyr, hvor jeg særligt vil fokusere på ironi og på hovedpersonen Frits' forhold til ironi. Men inden jeg når så langt, vil jeg starte med en læsning af Poul Møllers mere teoretiske skrifter og undersøge, hvordan Poul Møller herigennem udtrykker sin holdning til ironi, for siden hen - med Søren Kierkegaard - at indkredse, hvad romantisk ironi overhovedet er.

At begyndelsen hentes langt borte, vil dog for Poul Møller i »Om Begrebet Ironie« sige antikkens Grækenland. I antikkens Grækenland finder han nemlig en moralfilosofi, hvor »den naturlige Begjering betragtes som det Godes positive Side«, og hvor »Fornuften derimod er det begrænsende Princip« (»OBI«, p. 152). Siden antikken har disse to elementer, det naturlige begær og fornuften, skiftevis domineret i filosofihistorien. Efter antikkens Grækenland slår Poul Møller ned på den britiske filosofi, hvor han finder en dominans af fornuften til bestemmelse af det godes indhold. ${ }^{2}$ Dernæst kaster Poul Møller sig over Kant og Fichte, der modsat den britiske filosofi bestemmer det gode ud fra det naturlige begær. At Kant og Fichte således medvirker til en subjektivering af moralloven, medfører ifølge Poul Møller, at man heraf kan drage de mest forkastelige konsekvenser. Dette er især tilfældet hos Fichte, hvor den subjektive overbevisning betragtes »som det Høieste, idet Individets Villie identificeres med Moralloven«(»OBI«, p. 154).

1. Poul Møller: „Om Begrebet Ironie«, Efterladte Skrifter bd. 3, 2. udg., Kbh. 1848, p. 152; herefter forkortet »OBI«.

2. Uden at omtale det yderligere må Poul Møller med den britiske filosofi tænke på den engelske empirisme, der knytter sig til navne som Hume, Locke, Berkeley og Stuart Mill. 
Fra Fichtes videnskabslære, hvor vilje identificeres med moralloven, er der ikke langt til at sætte denne subjektive vilje over moralloven. Denne tendens finder Poul Møller »udtrykkeligt udtalt i F. Schlegels ligesaa frække som geniale Ungdomsskrift Lucinde«, hvor individet gang på gang føler sig hævet over moralloven (»OBI«, p. 155). $\mathrm{Og}$ når individet ser sig hævet over moralloven, kan dette bestemmes som ironi:

"I Særdeleshed er Ironien en conseqvent Fortsættelse af den frugtesløse Stræben, at bringe et i sig afsluttet Moralsystem i Stand blot fra Individets Standpunkt. Denne Fremgangsmaade maatte nødvendigviis ende med Savn af alt Indhold, med en moralsk Nihilismus« (»OBI«, p. 156).

Denne form for ironi kan ikke blot ses som én mulighed blandt andre, men må betragtes som et nødvendigt resultat af Fichtes »vildfarende Tankegang«. Samtidig understreges det, at denne vildfarende tankegang »kun har efterladt faa eller ingen Spor i vor Literatur« (»OBI«, p. 156).

I tilknytning til ironien vender Poul Møller sig nu mod, hvad han kalder den sygelige sentimentalitet, hvor man som i ironien føler sig »hævet over sine jordiske Pligter« (»OBI«, p. 157). Men hvor ironikeren sætter individet over moralloven, finder den sentimentale sit ideal både uden for sig selv og den synlige verden. Derfor holder både ironien og den sygelige sentimentalitet sig for gode til at beskæftige sig med jordiske pligter:

"Ironikeren, fordi hans individuelle Jeg er det Absolute; den Sentimentale, fordi hans Virkekreds i Livet ei er udenfor ham: han lever kuns et indre Liv, som fyldes med Længsler og Forudfølelse af det Tilkommende, som er det eneste Reelle« (»OBI«, p. 157).

Efter at have optegnet disse paralleller mellem sentimentalitet og ironi, der udelukkende skulle »tjene til at tydeliggjøre den hidtil omtalte practiske Ironie ved at sammenbringe den med den anden Art practisk Nihilisme», er det Poul Møllers udtrykkelige ønske igen at sætte fokus på ironien. Desværre når han aldrig så langt, da afhandlingen lidt abrupt slutter med ordene: »Vi gaae nu over til den poetiske Ironie. - -«(»OBI», p. 158).

Selv om Poul Møllers »Om Begrebet Ironie« slutter, inden diskussionen af poetisk ironi begynder, er det gennem Poul Møllers andre skrifter muligt at danne sig et indtryk af hans syn på denne. Især i anmeldelsen af Gyllembourgs Ekstremerne, hvor Schlegels Lucinde, der »ofte har været citeret som Ironiens Evangelium«, igen tages under behandling. ${ }^{3}$ Efter at have taget

3. Poul Møller: »Recension af »Ekstremerne««, Skrifter $i$ Udvalg bd. 2, Kbh. 1930, p. 147. 
romanens hovedperson til indtægt for at afvise enhver form for guddom, medmindre man er sin egen gud, fastslår Poul Møller:

"Dersom Kunstneren har bragt det til en saa fuldkommen Ironi, at alt uden for ham selv og hans Kunst, eller hans Kunst og ham selv, er ham fuldkommen ligegyldigt, da er det vist ogsaa forbi med hans Kunst; den sande Digter maa først og fremmest være et sandt Menneske. En abstrakt Kunstner, der uden for sin Kunst ikke har nogen alvorlig Vilje, ingen alvorlig Overbevisning, er ikke nogen ægte Kunstner. $\iota^{4}$

Den poetiske ironi er således den sande kunsts største fjende, eller som det lyder lidt senere: »den, der føler sig i Splid med sig selv og i Splid med den hele Tilværelse, han kan umulig være nogen sand Digter. ${ }^{5}$

Poul Møllers kritik af den ironiske subjektivitet er et gennemgående træk i store dele af forfatterskabet. I afhandlingen »Tanker over Muligheden af Beviser for Menneskets Udødelighed«lyder det f.eks., at med Fichtes system smuldrer subjektet væk i »en Sværm af hjælpeløse Atomer«. Derfor er »Ironiens Frihed«ikke en en sand frihed, da den ikke »ører til det rette Liv i Verden«. ${ }^{6}$ Det samme gør sig gældende i den mere kendte "»Indledning til en Afhandling om Affektation«, hvor Poul Møllers karakteristik af den tredje og sidste form for affektation, den vekslende, i det store hele synes identisk med hans opfattelse af en ironiker. Det fremhæves bl.a., at personen, der udviser en vekslende affektation, ikke har nogen »blivende Kærne i dets Tænken og Villen, men det dannede sig i ethvert Øjeblik af dets Liv en temporær Personlighed, for at ophæve den i det næste. ${ }^{7}$

Ligheden mellem Poul Møllers tanker og Søren Kierkegaards afhandling Om Begrebet Ironi - med stadigt Hensyn til Socrates fra 1841 er således iøjnefaldende. Både Møller og Kierkegaard undersøger ironien i en historisk kontekst, og begge kritiserer dens ensidige dyrkelse af subjektiviteten, som den navnlig kommer til udtryk i den tyske idealisme. ${ }^{8}$ Men hvor Kierkegaard ser ironiens subjektivitet som en linær historisk bevægelse - fra Sokrates og frem til romantikerne - ser Poul Møller filosofien som en vekslen mellem fornuften på den ene side og det subjektive begær på den anden. Hertil kom-

4. Loc.cit., p. 147

5. Loc.cit., p. 158.

6. "Tanker over Muligheden af Beviser for Menneskets Udødelighed «, Skrifter i Udvalg bd. 2, op.cit, p. 180 og 188.

7. „Indledning til en Afhandling om Affektation«, Skrifter i Udvalg, op.cit., p. 399. Se eventuelt også Poul Møllers strøtanker, hvor samme kritik af den uendelige subjektivitet gør sig gældende. Jvnf. Skrifter i Udvalg, bd. 2, f.eks. p. 272, 281, 283, 297, 317, 319 og 388. For en udlægning af Poul Møller som filosofisk tænker, hvor hans kritik af idealismen indtager en central stilling, se Uffe Andreasen: Poul Møller og romantismen, Kbh. 1973. 
mer, at Kierkegaards ærinde hovedsageligt er af religiøs karakter, mens Poul Møller i »Om Begrebet Ironie« forholder sig moralsk til ironien. ${ }^{9}$ Selv om Poul Møller i »Om Begrebet Ironie« hovedsageligt forholder sig moralsk til ironien, medtager han i udødelighedsafhandlingen også et religiøst aspekt i sin kritik af tysk idealisme. I denne afhandling understreges det bl.a., at en sygelig fiksering på subjektiviteten, som i Schlegels Lucinde, umuliggør troen på en guddom, der ikke er identisk med selvet, hvorfor den religiøse forestilling om udødelighed falder bort.

\section{Fichtes videnskabslære}

Som nævnt daterer Poul Møller udviklingen af den ironiske subjektivitet til Fichtes idealisme, en subjektivitet, der siden fik sit ypperste udtryk i Schlegels Lucinde. J.G. Fichtes filosofiske system, den såkaldte videnskabslære, var først og fremmest en revision af Kant og dennes begreb om »Das Ding an sich«, tingen i sig selv. Fichte understreger selv, at hans system »ikke er andet end det kantianske system. $\|^{10}$

Ifølge Fichte kan al filosofisk tænkning reduceres til to systemer: idealisme og dogmatisme. Hvor den idealistiske tænker tager udgangspunkt i jegets bevidsthed, ønsker den dogmatiske tænker at "fastsætte realiteten af tingen i sig selv, hvilket vil sige, at han vil fastsætte tænkningens nødvendighed af denne, som basis eller fundament for al erfaring« $(I$, p. 13 f.). Men en sådan dogmatisme baserer sig ifølge Fichte på et idealistisk grundlag, da enhver bestemmelse af tingen i sig selv nødvendigvis må tage udgangspunkt i jegets bevidsthed: »Tingen i sig selv bliver derfor til noget rent kimært, og der er således ingen videre grund til, at man fremover skal antage, at en ting overhovedet eksisterer i sig selv« $(I$, p. 16).

8. Vilh. Andersen skriver bl.a. om Kierkegaards afhandling, at »Haanden vel er Kierkegaards, men Aanden Poul Møllers«, hvilket støttes af J. Himmelstrup, der skriver, at »Kierkegaards Skildring staar i det hele næsten som en fortsættelse og videre udførelse af den paabegyndte Afhandling om den "moralske Ironi«, som foreligger fra Poul Møllers hånd«. Vilh. Andersen: Poul Møller, 3.udg., Kbh. 1944, p. 389. J. Himmelstrup: Søren Kierkegaards opfattelse af Sokrates - en Studie i dansk Filosofis Historie, Kbh. 1924, p. 39.

9. At det er muligt at opfatte Kierkegaards ærinde som værende hovedsageligt af religiøs karakter, kommer til udtryk i Om Begrebet Ironis afsluttende kapitel, »Ironi som behersket Moment. Ironiens Sandhed«. Her skriver Kierkegaard nemlig, som en direkte kritik imod de tyske romantikere, at selv om romantikernes »længsel efter et højere« er en virkelig længsel, så glemmer de dog, at »som Mennesket ikke skal adskille, hvad Gud har sammenføiet, saaledes skal det heller ei sammenføie, hvad Gud har adskilt«. Søren Kierkegaard: Om Begrebet Ironi - med stadigt Hensyn til Socrates, in: Søren Kierkegaards Skrifter, 4. udg., bd. 1, Kbh. 1997, p. 357.

10. J.G. Fichte: Introdutions to the "Wissenschaftslehre» and Other Writings (1797-1800), oversat og redigeret af Daniel Breazeale, Indianapolis \& Cambridge 1994, p. 4. Herefter forkortet $I$. 
Dette opgør med dogmatismen, der særligt er rettet mod Kant, gør Fichte i stand til at fastslå, at al tænkning tager udgangspunkt i og baserer sig på et jeg. Dette jeg »lader sig kun forstå, når det modstilles et ikke-jeg, og kun således, at jeget er bestemt inden for denne modsætning« $(I$, p. 42). Hvis al tænkning finder sted inden for kategorierne jeg eller ikke-jeg, er konsekvensen et filosofisk system, der udelukkende baseres på subjektivitet.

På baggrund af begreberne jeg og ikke-jeg er der al mulig grund til at kalde Fichte for jegets filosof. Men han er ikke jegets filosof i en traditionel dialektisk forstand. For en sådan dialektik ville forudsætte en subjekt/ objekt-relation, der umuliggøres med Fichtes afvikling af tingen i sig selv. Hvis Fichte skal forstås i dialektiske termer, er det nærmere en dialektik mellem jeg, ikke-jeg og det begrænsende jeg, hvor det begrænsende jeg gør det muligt at skelne mellem jeget og ikke-jeget. ${ }^{11}$

Med så mange forskellige jeg-kategorier, kan det ikke undre, at Poul Møller omtaler den af Fichte afledte subjektivitet som »en Sværm af hjælpeløse Atomer», der bl.a. manifesteres i »en temporær Personlighed«. Alligevel er det måske Georg Brandes, der i Den Romantiske Skole i Tyskland bedst har forklaret Fichtes indvirkning på romantikken:

„Fichtes Lære om det verdenssættende, verdensskabende Jeg stod i heftig Strid med »den sunde Menneskefornuft«. Netop dette var i Romantikernes Øjne et Hovedfortrin [...] og derfor fandt Romantiken i Jeglæren den Løftestang, men hvilken den troede at kunne løfte den gamle Verden ud af dens Hængsler. [...] I denne Opfattelse ligger Spiren til den berygtede romantiske Ironi«. ${ }^{12}$

Det er altså ikke uden grund, at Poul Møller daterer den ironiske subjektivitet til Fichtes videnskabslære.

\section{Fichte $i$ En dansk Students Eventyr}

Poul Møllers afstandtagen til Fichte og dennes idealisme kommer også til udtryk i En dansk Students Eventyr. Her møder man den lærde licentiat,

11. Med hensyn til Fichtes begrænsende jeg støtter jeg mig både til Paul de Mans »tropologiske« læsning af Fichte i »The Concept of Irony«, in: Aesthetic Ideology, Minneapolis \& London 1996, p. 172ff, og Radoslav A. Tsanoffs »Johann Gottlieb Fichte«, in: Paul Edwards (red.): The Encyclopedia of Philosophy, bd. 3, New York \& London 1967, p. 192-196.

12. Georg Brandes: Den Romantiske Skole i Tyskland, in: Hovedstrømninger $i$ det 19. Aarhundredes Literatur, bd. 1, København \& Kristiania 1906, p. 231 . 
der i alle henseender angriber verden intellektuelt. Da han forsøger at forklare sin fætter Bertel, hvorfor han aldrig får udrettet noget, lyder det:

„Fremdeles kommer jeg til at tænke paa mine Tanker derover, ja jeg tænker over at jeg tænker derover, og deler mig selv i en uendelig tilbageskridende Rad af Jeger, der betragter hinanden. Jeg ved ikke, hvilket Jeg der skal standses ved som det egentlige, og i det Øjeblik jeg standser ved et, er det jo igen et Jeg, der standser derved. $«^{13}$

Licentiatens udlægning af sin lange række af jeger, er tydeligvis en karikeret fremstilling af Fichtes tanker. Licentiaten er et udtryk for, hvorledes Fichtes tanker om jeget kan gøre stor skade på det tænkende subjekt. Men at licentiaten som en levendegørelse og konkretisering af Fichtes system ikke kun er lammet i sine tanker, men i hele sit handlende væsen, viser sig bl.a., da Bertel spørger, hvorfor han er begyndt at studere mineralogi. Licentiaten svarer, at det er, fordi hans studier i mineralogien gør ham i stand til at skrive bedre:

»Jeg har bemærket, at Tankerne glide bedst fra Pennen, naar man besidder aldeles hensigtsmæssige Skriveredskaber. For at faa gode Penne, maa man have gode Knive, og for at skærpe dem maa man besidde ret udsøgte Slibestene. Derfor har jeg, inden jeg gik videre, forskrevet adskillige Stenarter, og rigtignok, som du ser, maatte trænge temmelig dybt ind i Mineralogien som et forberedende Studium« (Stud., p. 294). ${ }^{14}$

Denne tydelige karikatur viser, at studiet af Fichte intet positivt fører med sig: at licentiaten ikke kan holde styr på sine jeger er én ting, men at han konkretiserer denne uendelige række af jeger i den materielle verden, gør ham fuldstændig handlingslammet selv ved så simpel en handling som at skærpe pennen.

Med denne fremstilling af licentiaten distancerer Poul Møller sig endnu engang fra Fichtes jeg-lære, som romantikken ifølge Brandes brugte som en "Løftestang, med hvilken den troede at kunne løfte den gamle Verden ud af dens Hængsler«. Men at Poul Møller måske ikke er helt så konsekvent i sin afvisning af Fichtes jeg-lære, og at han faktisk benytter sig af romantisk

13. En dansk Students Eventyr, in: Skrifter i Udvalg, bd. 1, p. 293; herefter forkortet Stud.

14. Senere i romanen spørger licentiaten retorisk Frits: „Hvorledes kan nogen Tanke fødes, da den altid maa have været til, før den blev til? [...] Saaledes gaar det frem i det uendelige, og denne Uendelighed begrænses af et Øjeblik [...] Indsigten af Tankens Umulighed indeholder selv en Umulighed, og Erkendelsen heraf frembringer paa ny en uforklarlig Modsigelse« (Stud., p. 326). 
ironi, skal vi se nærmere på i det følgende, efter en diskussion af, hvad ironi overhovedet er for noget.

\section{En dansk Students Eventyr - en læsning af ironi med Kierkegaard}

En dansk Students Eventyr er uden tvivl Poul Møllers mest kendte værk og anses generelt for at betegne et gennembrud for dansk poetisk realisme. Romanens tilblivelseshistorie må forudsættes velkendt: fra historisk roman til en samtidig studenterroman, og Poul Møllers oplæsning af de tre første kapitler i Studenterforeningen i 1824. Men også at der er tale om et romanfragment, der først blev rekonstrueret og udgivet i Efterladte Skrifter i 1843, fem år efter Poul Møllers død. ${ }^{15}$

I begyndelsen af En dansk Students Eventyr følger man en flok studenter, der er på vej ud af byen for at besøge deres studiekammerat, Balthasar. Knapt ankommet, udbryder én af dem: »O, havde vi nu den krøllede Frits [...] da kunne vi være vis paa en herlig Aften«. En anden svarer, at Frits sjældent svigter godt selskab, men anlægger dog en mere kritisk tone over for Frits' personlighed. Det lyder, at Frits ofte "taber sig med blind Ubesindighed i Øjeblikkets Nydelse«, og at han er som den »karakterløse Kamæleon, der bestandig antager sine Omgivelsers Farver« (Stud., p. 257).

Allerede i åbningsscenen tydeliggøres flere af de spor, som kan følges gennem resten af romanen: at romanen foregår i et studentermiljø, hvor studenterne ofte forsøger intellektuelt at indkredse den fraværende Frits' omskiftelige karakter. Derfor finder man i romanens første halvdel Christians og Bertels fortællinger om henholdsvis Frits' barndom og om hans slagsmål med en vægter aftenen før; episoder, der begge findes i udkastet til den historiske roman. ${ }^{16}$ Siden møder vi også Frits’ egen selviscenesættelse gennem brevene fra Møllerkroen.

15. Jvnf. Vilh. Andersens Poul Møller, op.cit., p. 187ff. Vilh. Andersen omtaler konsekvent En dansk Students Eventyr som Novellen - en betegnelse, som bl.a. videreføres af Hans Brix. Imidlertid har John Chr. Jørgensen overbevisende argumenteret for, at En dansk Students Eventyr er en roman og ikke en novelle. Da jeg her deler Jørgensens synspunkt, og i øvrigt finder, at En dansk Students Eventyr har en flertrådet handling, hvilket ofte benyttes til at adskille roman fra novelle, adopterer jeg uden yderligere diskussion af genren John Chr. Jørgensens betegnelse. Jvnf. Hans Brix: Analyser og Problemer, bd. 2, Kbh. 1935, p. 275293 og John Chr. Jørgensen: Den sande kunst. Studier i dansk 1800-tals realisme, Kbh. 1980, p. 64-75.

16. Udkastet til den historiske roman, der finder sted i reformationstidens Danmark, er ligeledes optrykt i Skrifter i Udvalg, bd. 1: Vægterscenen, hvor Frits (i den historiske roman Silvio) antastes som tyv, da han gennem skorstenen vil aflytte sin "udkårne«, og barndommens flugt fra onklen, hvor Frits (Silvio) ender som spillemand. Jvnf. udkastet til den historiske roman, p. 20lf og $239 f$. 
Efter Christian og Bertels fortællinger om Frits og hans flygtige forelskelser påbegynder studenterne en diskussion om kærlighed. Bertel forklarer, hvorledes han "henregner alle Elskere til tre Klasser«. Og om den sidste klasse af elskere hedder det - med tydelig allusion til Poul Møllers karakteristik af den vekslende affektation - at for at blive "Genstand for denne klasses Kærlighed udfordres slet ingen Egenskaber; dem lægger Elskeren aldeles til af egne Midler«, hvorfor disse elskere »bestandig se deres elskede med en Glorie om sin Tinding« (Stud., p. 278). At Bertel med bestemmelsen af denne tredje klasse af elskere bl.a. har Frits i tankerne, bliver klart, da Frits straks efter træder frem og synger en kærlighedssang for studenterne.

Med studenternes forskellige forsøg på at indkredse Frits, får vi antydet nogle karakteristika i Frits' personlighed, der også kendes fra den romantiske ironiker. Spørgsmålet er dog, om det er muligt at karakterisere dette som et udtryk for ironi, og hvordan en sådan form for ironi overhovedet lader sig bestemme. For at svare på dette, vil jeg i det følgende inddrage Søren Kierkegaards Om Begrebet Ironi, da denne afhandling af Poul Møllers elev i forskellige sammenhænge er blevet karakteriseret som »den bedste bog om ironi der findes. ${ }^{17}$

Kierkegaards synsvinkel i Om Begrebet Ironi er et åndsfænomenologisk syn, som han hovedsageligt henter fra Hegel. Herfra viser Kierkegaard, hvordan ironiens første tilsynekomst i verdenshistorien må falde sammen med fremkomsten af subjektiviteten. Og gennem læsninger af Xenophon, Platon og Aristophanes' fremstillinger af Sokrates kan Kierkegaard bestemme, at det »er Subjectivitetens uendelige overgivne Frihed, vi see i Socrates" og videre, at »dette er netop Ironien. ${ }^{18}$

Sokrates' ironiske standpunkt står for Kierkegaard »i Verdens-Aandens Tjeneste« $(O$, p. 311$)$, for »idet han tilintetgjorde Græciteten, brugte han ironien; hans Adfærd mod den var bestandig ironisk« (O, p. 302). Men efter Sokrates »forsvandt den [dvs. ironien] ikke atter sporløst, Verden sank ikke atter tilbage i dens tidligere Udviklingsform, tvertimod, det Gamle forsvandt, og Alt blev nyt« $(O$, p. 282). Derfor må en ny historisk orienteret ironisk fremtrædelsesform være en slags subjektivitet i en højere form. »Det maa«, skriver Kierkegaard, »da være en Subjectivitetens anden Potens, en Subjectivitetens Subjectivitet, der svarer til en Reflexionens Reflexion« $(O, \mathrm{p}$. 282). Mens Sokrates' ironi var verdenshistorisk berettiget, idet den blev "beroliget derved at Subjectiviteten skete sin Ret, saa blev den anden Form af Ironi bekjæmpet og tilintetgjort; thi da den var uberettiget, kunde den

17. Her: Paul de Man: »The Concept of Irony«, in: Aesthetic Ideology, Minneapolis \& London 1996, p. 163.

18. Kierkegaard: Om Begrebet Ironi, op.cit., p. 255. Herefter forkortet $O$. 
kun skee sin Ret derved, at den blev ophævet« $(O$, p. 282). Og den anden form for ironi, Kierkegaard tænker på, er netop den romantiske.

Kierkegaard opstiller nu tre karakteristika, der gør sig gældende i alle former for ironi. Udgangspunktet er den ironiske talefigur »at sige det Modsatte af hvad man mener« $(O$, p. 286). Dermed »have vi allerede en Bestemmelse, der gaar gjennem al Ironi, den nemlig, at Phonomenet ikke er Voesenet, men det Modsatte af Væsenet«(O, p. 286). Dette medfører, hvis opmærksomheden rettes mod »det talende Subject», endnu en bestemmelse »der gaar gjennem al Ironi, Subjectet er nemlig negativt frit« (O, p. 286). Som sidste bestemmelse, der »ogsaa er eiendommelig for al Ironi«, nævner Kierkegaard »en vis Fornemhed, som hidhører fra, at den, om den end vil forstaaes, dog ikke vil ligefrem forstaaes; som gjør, at denne Figur ligesom seer ned paa den slet og rette Tale, hvilken Enhver øieblikkelig kan forstaae: den reiser ligesom i et fornemt Incognito, og seer fra dette høie Stade medlidende ned paa den almindelige pedestre Tale« $\left(O\right.$, p. 287).$^{19}$

Med disse tre bestemmelser påbegynder Kierkegaard sin historiske afklaring af begrebet ironi. I afhandlingens første del påviser han, at Sokrates historisk gjorde subjektiviteten mulig, og da ironien er "Subjectivitetens første og abstracteste Bestemmelse« (O, p. 302), må den historiske afklaring derfor begynde med Sokrates. Sokrates står for Kierkegaard som repræsentant for en historisk berettiget ironi, da han gør op med "græciteten«. Og som modsætning hertil ser Kierkegaard den romantiske ironi, der ikke er historisk berettiget.

Forskellen mellem den sokratiske og den romantiske ironi, som udelukkende er deres historiske berettigelse, kommer også til udtryk, når Kierkegaard bestemmer ironi som uendelig absolut negativitet:

„Den er Negativitet, thi den negerer blot; den er uendelig, thi den negerer ikke dette eller hiint Phænomen; den er absolut, thi det, i Kraft af hvilket den negerer, er et Høiere, der dog ikke er. Ironien etablerer Intet; thi det, der skal etableres, ligger bag ved den« $\left(O\right.$, p. 299). ${ }^{20}$

19. De første to af disse tre bestemmelser henter Kierkegaard fra Hegels Ästhetik. Her bestemmer Hegel ligeledes ironi som fænomenet værende det modsatte af væsenet, og at subjektet er negativt frit. Kierkegaards sidste bestemmelse - en vis fornemhed - har sandsynligvis også sin oprindelse hos Hegel, dog mere indirekte. For i sin omtale af Friedrich Schlegel omtaler Hegel ham konsekvent som Friedrich von Schlegel og antyder dermed, at Schlegel gennem brugen af ironi netop bliver fornem. Afsnittet om ironi fra Hegels $\ddot{A}$ sthetik er oversat til dansk som »Ironien«, in Passage, nr. 17 (1994), pp. 93-99.

20. Ironi som den uendelige absolutte negativitet er ligeledes en bestemmelse, som Kierkegaard henter fra Hegels $\ddot{A}$ sthetik. 
Ud fra denne bestemmelse må Kierkegaard altså også skelne mellem en historisk berettiget uendelig absolut negativitet og en uberettiget. Og her er Sokrates' ironi netop historisk berettiget, da »det ikke [var] Virkeligheden overhovedet, han negerede, men det var den til en vis Tid givne Virkelighed, Substantialitetens, saaledes som den var i Grækenland« $(O$, p. $307 f$.). Så vidt kom det dog aldrig med den romantiske ironi:

„For det Første forvexlede man det empiriske og endelige Jeg med det evige Jeg; for det Andet forvexlede man den metaphysiske Virkelighed med den historiske Virkelighed. Man anvendte saaledes et ufuldbaarent metaphysisk Standpunkt uden videre paa Virkeligheden [...] Det var ikke et Moment af den givne Virkelighed, der skulde negeres og fortrænges; men det var al historisk Virkelighed, den negerede, for at skaffe Plads for en selvskabt Virkelighed«(O, p. 311).

Hvad romantikerne ifølge Kierkegaard ikke forstår, er, at den historiske virkelighed viser sig "deels som en Gave, der ikke vil lade sig vrage, deels som en Opgave, der vil realiseres« $(O$, p. 312). Gaven, Kierkegaard her taler om, udtrykker »Individets Forhold til en Fortid«: en fortid der ikke kan »oversees eller ignoreres« $(O$, p. 313). Men romantikerne »havde med det evige Jeg forvexlet det timelige Jeg. Men det evige Jeg har ingen Fortid, og altsaa har det timelige det heller ikke« $(O$, p. 313$)$. Forvekslingen af det timelige og evige jeg indebærer, at romantikerne ikke kan modtage virkeligheden som en gave.

Dette får konsekvenser for den opgave, som virkeligheden stiller til individet. Fordi det »handlende Individ skal være istand til at løse sin Opgave i at realisere Virkeligheden, maa det føle sig indordnet i en større Sammenhæng« $(O$, p. 315). Men ironien forsøger bestandigt at frigøre sig fra denne sammenhæng og kan ikke modtage virkelighedens velsignelse: "thi da den intet Høiere har end sig selv, kan den ingen Velsignelse modtage« $(O$, p. 315$)$. Men at den intet højere har end sig selv, er et udtryk for den romantiske ironis higen efter frihed:

"Den vaager derfor over sig selv, og frygter Intet mere, end at et eller andet Indtryk skal overvælde den; thi naar man er saaledes fri, da først lever man poetisk, og det var som bekjendt Ironiens store Fordring, at man skulde leve poetisk« $(O$, p. 316).

Et poetisk liv kan realiseres på to måder: „Eet er nemlig at digte sig selv, et Andet at lade sig digte«. Den »Christne lader sig digte« og anerkender, at »der er sat ham en Opgave« $(O$, p. 316). Således lever den kristne i en historisk 
sammenhæng og udsiger på grund af den historiske berettigelse »ikke et Ord uden Mening«, men for den romantiske ironiker »har denne Sammenhæng [...] ingen Gyldighed« $(O$, p. 318), og da han ikke vil passes ind i omgivelserne, må omgivelserne passes ind efter ham: "han digter ikke blot sig selv, men han digter ogsaa sin Omverden« $(O$, p. 318$)$.

For Kierkegaard opstår den romantiske digtning i en vekselvirkning mellem en given og en ideal virkelighed. Den givne virkelighed er for romantikerne en karikeret spidsborgerlighed, hvor alt foregår på klokkeslæt: »Man sværmede i Naturen St. Hansdag, man var sønderknuset store Bededag, man forliebede sig, naar man fyldte sit 20de Aar, man gik i Seng Klokken 10« $(O$, p. 336). Når den givne virkelighed for romantikerne fremstår så karikeret, bliver idealet højere og mere sprudlende. Det højeste ideal for romantikerne er ifølge Kierkegaard drømmeverdenen, og i sin fremstilling af det romantiske ideal viser Kierkegaard, hvor grinagtigt dette ideal er: »Poesien vaagner, de stærke Længsler, de hemmelighedsfulde Ahnelser, de begeistrende Følelser, Naturen vaagner, den fortryllede Prindsesse vaagner - Romantikeren falder i Søvn« (O, p. 337). Da det romantiske ideal kommer fra en karikeret virkelighedsopfattelse, betyder det, at »den Kilde, der her sprudler, ikke sprudler til et evigt Liv. Men netop dette, at denne Poesi bevæger sig mellem Modsætningerne, viser, at den ikke er i dybere betydning sand Poesi« (ibid.).

Den romantiske poesi ordner sig ikke »i en poetisk Totalitet«, som den religiøse gør $(O$, p. 338). Det skyldes ifølge Kierkegaard, at den er en polemisk stræben, der aldrig finder hvile, »thi det Poetiske bestaar netop i bestandig at frigøre sig ved en ny Polemik« (O, p. 338). Og uden et poetisk ideal bliver den romantiske poesi en uendelig allegori:

"Den ideale Stræben har atter intet Ideal; thi ethvert Ideal er i samme Øieblik dog blot en Allegori, der skjuler et høiere Ideal i sig, og saaledes i det Uendelige. Digteren under derfor aldrig hverken sig selv eller Læseren Ro, thi Ro er netop slig Digtens Modsætning. Den eneste Ro, den har, er den poetiske Evighed, hvori den seer Idealet, men denne Evighed er en Uting, da den er uden Tid, og derfor bliver Idealet i næste Øieblik Allegori« (O, p. 338f).

Da den romantiske ironi ikke ser den historiske virkelighed som en gave, kan den ikke videreføre historiens opgave. Den kan blot forholde sig karikeret til sin samtid og formår derfor ikke, som Sokrates' ironi at være »i VerdensAandens Tjeneste«. Et karikeret forhold til éns samtid betyder også, at der er tale om en ideal stræben uden et endeligt ideal, da idealet netop er at være i modsætning til samtiden, hvorfor idealet bliver uendeligt. Den romantiske 
ironi og dens uendelige stræben mod poetisk frihed bliver derfor en allegori, »der skjuler et høiere Ideal i sig, og saaledes i det Uendelige« $(O$, p. 338).

Med udgangspunkt i Kierkegaards opfattelse af ironi, åbnes der for muligheden af at karakterisere Frits som ironiker. F.eks. når studenterne omtaler Frits som den »karakterløse Kamæleon, der bestandig antager sine Omgivelsers Farver« (Stud., p. 257), falder det fint i tråd med Kierkegaard, når han om de romantiske ironikere skriver, at de konstant negerede den historiske virkelighed »for at skaffe Plads for en selvskabt Virkelighed « $(O, \mathrm{p}$. 311). Således digter Frits sig selv, i stedet for at lade sig digte. Eller med Kierkegaards ord om den romantiske ironiker: "han digter ikke blot sig selv, men han digter ogsaa sin Omverden« $(O$, p. 318). Videre er det gennem de tre karakteristika, »der gaar gjennem al Ironi«, muligt at bestemme Frits' karakter som ironisk. ${ }^{21}$ Særlig i forhold til Frits' iscenesættelse af sit eget selvmord, som jeg senere vil vende uddybende tilbage til, og hans efterfølgende beretning herom til studenterne. Her er der flere eksempler på, hvordan Frits siger det modsatte af, hvad han mener, og dermed hvordan væsenet bliver det modsatte af fænomenet, hvilket giver Frits en negativ frihed, der igen gør ham en smule fornem i forhold til de øvrige studenter.

Frits er måske ikke den ideelle romantiske ironiker, og der er vel heller ingen tvivl om, at det er et noget karikeret billede, Poul Møller har skabt af en ironiker. Dette kaster naturligvis endnu et ironisk skær over romanen. Med bestemmelsen af Frits som ironiker bliver det muligt at læse Frits færd ud i verden som en art allegori, hvor han søger et fast grundlag, en endelig signifié, der kan befri ham fra ironiens fængsel. Inden vi skal se nærmere på Frits' videre færd, skal vi dog først se, hvordan ironien manifesterer sig på flere niveauer i romanen, ikke kun tematisk, men også formelt.

\section{Ironi og komposition}

Den fortællemæssige struktur i En dansk Students Eventyr er temmelig kompleks. Særlig i romanens to første kapitler synes indskud og digressioner at spille en væsentlig rolle, hvorfor den overordnede tredjepersonsfortæller træder noget i baggrunden. Udgangspunktet er som bekendt stadig hos Balthasar, hvor studenterne mødes og diskuterer Frits' karakter. Første kapitel

21. I en læsning af »Diapsalmata« fra Enten-Eller benytter Winfield E. Nagley Kierkegaards tre bestemmelser af ironi som teoretisk grundlag for en indkredsning af ironi i Enten-Eller. Jvnf. Winfield E. Nagley: "Irony in the "Diapsalmata«, in: Thulstrup \& Thulstrup (red.): Bibliotheca Kierkegaardiana, bd. 9, Kbh. 1981, p. 24-55. 
domineres i nogen grad af Bertels og Christians indskudte fortællinger om henholdsvis Frits' barndom og hans forsøg på at aflytte Sophies værelse gennem en skorsten. Andet kapitel domineres af oplæsningen af de breve, som Frits sender studenterne fra Møllerkroen, der dog afbrydes af en længere digression om licentiaten. Denne fortællemæssige kompleksitet accentueres både af Frits, da han vender tilbage og giver studenterne flere forskellige muligheder at vælge mellem i fortællingen om sit selvmordsforsøg, og af romanens indlagte sange og digte.

Et andet væsentligt træk ved En dansk Students Eventyr er dens genremæssige ubestemmelighed. Der skiftes flere gange mellem fortælling, brevroman, bekendelser og lyrik, hvorfor de genremæssige karakteristika synes at antyde, at der ikke findes noget endeligt. Hver gang man synes at være blevet fortrolig med romanen, skiftes der til en ny fortælleinstans og fortælleposition, som man f.eks. kender det fra Sternes Tristam Shandy. Dette skift i fortælleposition følges i En dansk Students Eventyr oftest af en ændring i genre, hvad enten der er tale om de indlagte fortællinger, den tydelige allusion til brevromanen eller Frits' bekendelser over for studenterne.

Gennem brugen af forskellige fortælleinstanser og genrer synes En dansk Students Eventyr at understøtte, hvad vi tidligere har set i karakteristikken af Frits: den ironiske udfoldelse, hvor det ikke er muligt at fastholde noget endeligt. De hyppige genreskift og ændringer i fortælleforhold underbygger samtidig de krav, som Friedrich Schlegel stiller til en tidstypisk roman i Gespräch über die Poesie. I afsnittet »Brief über den Roman« skriver Antonio, at »jeg ikke kan forestille mig en roman som andet end en blanding af fortælling, sang og andre former. $\aleph^{22}$ Det skyldes, forklarer Antonio videre i Gespräch über die Poesie, at en sådan genreblanding udtrykker »en sand arabesk, der sammen med bekendelser [...] er de eneste romantiske naturprodukter af vor tidsalder. ${ }^{23}$ Med den genremæssige sammenblanding ekspliciterer En dansk Students Eventyr umuligheden af at fastholde en enkelt betydning. Samtidig understreger sammenblandingen også det specifikt romantiske, da romanens mange digressioner og fortællemæssige labyrinter leder tankerne hen på arabesken, som ifølge Antonio er en af romantikkens eneste opfindelser. ${ }^{24}$ Genrekompleksiteten er således et udtryk for en bevægelse, der i det store og hele er at ligne med ironi, hvorved det

22. Kritische Friedrich-Schlegel-Ausgabe, bd. 2, München, Paderborn \& Wien 1963-1967, p. 336.

23. Op.cit., p. 337.

24. Ifølge Marie-Louise Svane er det i romantikken almindeligvis »det litterære værks narrative struktur, der betegnes som arabesk«. Jvnf. Marie-Louise Svane: »Arabesk. En romantisk grænsefigur«, in: Ny Poetik. Tidsskrift for litteraturvidenskab 7, Odense Universitetsforlag, Odense 1997, p. 94. 
bliver muligt at tolke romanens fortællemæssige og genremæssige forhold som et udtryk for romantisk ironi.

Ud over at en roman helst skal være en blanding af flere forskellige genrer, er Antonio i Gespräch über die Poesie også af den opfattelse, at en roman altid bør indeholde sin egen teori, hvorfor enhver "teori om romanen selv burde være en roman. ${ }^{25}$ Hvis man i En dansk Students Eventyr skal forsøge at indkredse den form for "teori i romanen", som Antonio her taler om, synes suspenderingen af ethvert endeligt at være et godt udgangspunkt, da det hverken genre- eller fortællemæssigt synes muligt at indkredse romanen. Derfor vil jeg i det følgende illustrere, hvordan denne suspendring af ethvert grundlag udtrykkes i resten af romanen, og hvorfor romanen derfor kan læses allegorisk som Frits’ forsøg på at finde noget endeligt betegnende, der kan frigøre ham fra ironiens fængsel.

\section{Frits' iscenesættelse}

Efter at have sunget sangen »Søde! sig, hvornaar jeg dig skal finde« om sin længsel efter den ukendte elskede, drager Frits ud i verden som en »spædlemmet Fugl i Luften, der trøstig begiver sig paa Flugten over de mange tusinde Bølger, uden at være sikker paa at finde det Træ, den flyver efter« (Stud., p. 282).${ }^{26}$ Med denne analogi røber Frits, at han ikke blot rejser ud for at lede efter sin kommende elskede, men at han i lige så høj grad rejser ud for at finde noget endeligt betegnende - som fuglen efter et bestemt træ - uden nogen sikkerhed for, at det virkelig findes.

Gennem en række breve, som Frits sender til studenterne derhjemme, og som Balthasar læser højt for studenterne, fortæller Frits, at han nu befinder sig på Møllerkroen, hvor han er blevet forelsket i møllerens datter Marie. I modsætning til den tidligere mere spontane forelskelse i Sophie virker Frits' forelskelse i Marie anderledes afbalanceret og eftertænksom; et indtryk der understreges gennem de idylliske beskrivelser af Marie, som leder tankerne hen på malerkunstens genrebilleder. ${ }^{27}$

Trods de idylliske beskrivelser og den tilsyneladende afbalancerede nye Frits, der med sit brevskriveri leder tankerne hen på Goethes Werther, er stu-

25. Op. cit., p. 336.

26. Sangen »Søde! sig, hvornaar jeg dig skal finde« er i øvrigt med få ændringer identisk med første digt i Poul Møllers digtkreds »Til Laura».

27. F.eks. skriver Frits, at Maries beskedne påklædning er det "klareste Udtryk af den stille Ligevægt og Ynde, der hersker i hele hendes Væsen" (Stud., p. 299). Allusionen til malerkunstens genrebillede understreges også i Frits' kommentarer, efter at han en morgen ubemærket har set Marie gå tværs over gården: »denne korte Vandring staar bestandigt som det skønneste Maleri for min Fantasi« (Stud., p. 300). 
denterne ikke overbeviste om, at Frits i Marie har fundet det stabile grundlag, som han drog ud i verden for at finde. I stedet mener f.eks. Bernhard, at forelskelsen i Marie blot er endnu et eksempel på, at Frits er at ligne med en "Kamæleon, der bestandig antager sine Omgivelsers Farver«:

"Hans Karakter er omskreven af en saa elastisk Ring, at den bestandig omformes efter den Kres, han befinder sig i [...] og jeg tvivler ikke paa, at han i Møllerens Hus antager en Farve, som behager den uerfarne Landsbypige« (Stud., p. 298). ${ }^{28}$

Som om Frits i nogen grad kan forudse studenternes reaktion på sin nye forelskelse, giver han dem i næste brev svar på tiltale: „den 2lde i næste Maaned vil vi holde Bryllup«(Stud., p. 303). Inden da vil han dog "gøre Marie en ordentlig Kærlighedserklæring«, hvorfor hun åbenbart ikke er bekendt med Frits' planer. Ved samme lejlighed sender Frits studenterne et kærlighedsdigt, der er dediceret til Marie. At Frits sender digtet til studenterne og på intet tidspunkt viser det til Marie, afslører, at digtet først og fremmest er et forsøg på at overbevise studenterne om, at hans kærlighed til Marie både er dyb og oprigtig, og at han med hende har fundet en vej ud af ironien.

I digtet antydes det allerede i de første linier, at det handler om Frits' egen længsel efter stabilitet: »Nu har jeg længe nok i Livet sværmet / Ret som en Fuglefjer for alle Vinde«. Men efter at Frits har mødt Marie, behøver han ikke længere at sværme rundt for alle vinde: „Nu ligger jeg i Havnen trygt beskærmet, / Jeg fundet har en dejlig Frelserinde«. Med forelskelsen i Marie tror Frits, at han har fundet en frelserinde, der kan gøre en ende på hans sværmeriske og ironiske liv. Men at dette ikke er tilfældet, og at Frits' tro må afvises som illusorisk, berøres i slutningen af digtet. Efter en række invokationer lyder den lidt overraskende slutning: »Og vilde hvert et $\mathrm{Næb}$ i Luften synge: / Da - «. Denne abrupte slutning følges af Frits’ egen kommentar i brevet til studenterne: »Da - derpaa kan jeg ingen Slutning sætte. Jeg mangler et Rim« (Stud., p. 305). At Frits ikke kan finde et rim tyder på, at han interesserer sig mere for digtets sproglige udtryk og perfektion end for at udtrykke sin påståede kærlighed til Marie. Så med interessen rettet

28. Jvnf. Bertels tidligere karakteristik af den tredje klasse af elskere, hvor det lyder, at for at "blive Genstand for denne Klasses Kærlighed udfordres slet ingen egenskaber; dem lægger Elskeren aldeles til af egne Midler« (Stud., p. 278). Samme tankegang gør sig som bekendt gældende i affektationsafhandlingen, hvor den vekslende affektation forklares ved, at den "snart antager denne, snart hin bestemte Skikkelse«. Jvnf. Skrifter i Udvalg, bd. 2, p. 399. Hos Kierkegaard findes som nævnt en lignende karakteristik af den romantiske ironiker: "han digter ikke blot sig selv, men han digter ogsaa sin Omverden«. Jvnf. Kierkegaard: Om Begrebet Ironi, p. 318. 
mod digtets sproglige udtryk er det ikke længere muligt at læse digtet som en beskrivelse af, hvordan Frits har fundet frelse for ironien. Tværtimod indikerer interessen for digtets sproglige udtryk, at forelskelsen i Marie ikke kan tilbyde Frits det stabile grundlag, som han søger.

At digtet ikke bør læses som en kærlighedserklæring til Marie, understreges også af Bertels efterfølgende tolkning, da Balthasar har læst digtet op for studenterne. Ifølge Bertel er digtet »en poetisk Fiktion, som staar der blot for at pynte, uden at det skal have nogen egentlig Betydning« (Stud., p. 305). Digtet udtrykker således en form for iscenesættelse, hvor Frits uden held prøver at overbevise studenterne om, at Marie er hans frelse for et liv i ironiens magt. Hvorfor Frits nødvendigvis må iscenesætte sit liv og gang på gang må postulere, at han har fundet stabilitet for ironiens uendelighed, kommer tydeligst til udtryk i handlingsforløbet omkring det efterfølgende selvmordsforsøg.

\section{Det iscenesatte selvmord}

Da studenterne igen samles for at høre om resultatet af Frits' frieri, venter der dem et sørgeligt budskab: "Naar I modtage dette Brev, har jeg selv gjort en Ende paa mit Liv«, lyder det i brevet fra Frits (Stud., p. 306). Videre fortæller han, at ønsket om at begå selvmord skyldes, at hans liv kun har "været et stygt, elendigt Gøglespil«(Stud., p. 307). Men at ønsket om at begå selvmord måske i lige så høj grad udspringer af Maries afslag på hans frieri, nævnes ikke i afskedsbrevet. Kort testamenterer Frits sine få ejendele til studenterne og afslører igen sin forkærlighed for det iscenesatte, da han forestiller sig, at Christian en aften vil besøge hans grav med dét valdhorn, som er testamenteret til ham: "sæt dig da en Aften paa min Gravhøj i stille Vejr og blæs en Sørgemarsch ud over Søen« (Stud., p. 306). Dette forsøg på at iscenesætte en hændelse, der skal finde sted efter døden er indtruffet, vidner om, hvordan hele selvmordsforsøget udelukkende er iscenesat af Frits til ære for studenterne derhjemme.

Efter oplæsningen af afskedsbrevet bryder flere af studenterne ud i gråd. De er alle fortvivlede over, at en "saa flygtigt opstaaet Lidenskab« har kunnet overvælde Frits »med en saadan Voldsomhed«(Stud., p. 306). Der breder sig derfor »en dyb Stilhed i den hele Kres«, der først afbrydes, da Frits træder frem og spiller en »højtidelig Dødningemusik paa et Valdhorn« (Stud., p. 306). Studenterne bliver naturligvis glædeligt overraskede over at se Frits, som de troede havde gjort en ende på sit liv. Men Balthasar, der tidligere blev anklaget for at forholde sig "saa kold og hjærteløs« under sin oplæsning af afskedsbrevet, erkender, at han hele tiden vidste, at Frits ikke havde begået 
selvmord. Hele situationen med oplæsningen af afskedsbrevet og den senere genkomst er derfor - med Balthasars vidende - iscenesat og udspillet af Frits til ære for studenterne og sig selv.

Frits illustrerer således endnu engang sit behov for at forstille sig: på grund af ironiens suspendering af ethvert grundlag ser han sig nødsaget til at iscenesætte sit liv for at bevare illusionen om, at han har fundet det stabile grundlag, som han søger. Behovet for hele tiden at iscenesætte sit eget liv kan derfor ikke bare afvises som et kapriciøst indfald. Der er i stedet tale om et slags eksistensvilkår, der har den uheldige effekt, at jo mere Frits må iscenesætte sit liv i et forsøg på at bevare illusionen om en endelig signifié, jo længere bevæger han sig væk fra muligheden af nogensinde at nå en sådan.

Da Frits efter oplæsningen af afskedsbrevet atter træder ind i studenternes kreds, forklarer han, at »nu skal jeg kortelig fortælle min Død og min Genfødsel«(Stud., p. 308). Ordvalget her er yderst interessant. Der er nemlig ikke tale om, at han vil fortælle om sin død og genfødsel, men blot at han vil fortælle sin død og genfødsel, som om de først bliver faktiske hændelser i det øjeblik, Frits sprogligt sætter ord på dem. At ordvalget er helt bevidst, understreges i selve Frits' rekonstruktion af selvmordsforsøget, hvor det bliver mere og mere tydeligt, at der er tale om en fortælling, som Frits opdigter, mens han fortæller den. Frits lægger i sin fortælling ud med at slå fast, at han virkelig forsøgte at hænge sig, men desværre blev skåret ned igen "mod min Vilje og mit Vidende», hvad der siden viser sig at være usandt (Stud., p. 308). At Frits forsøger at overbevise studenterne om, at han blev skåret ned mod sin vilje, giver hans fortælling den dramatiske effekt, at studenterne hele tiden er klar over, at der er tale om en historie, der involverer liv og død. ${ }^{29}$ Så da Frits efterfølgende fortæller, at Marie uden videre afslog hans frieri, er man straks klar over, at hun gennem sit afslag næsten førte ham i døden.

Frits forklarer videre, at han straks reagerede på Maries afslag: »Jeg blev naturligvis yderst forbitret og slog i Bordet«, lyder det. Denne dramatiske forklaring om Frits' umiddelbare handlekraft godtager Bertel ikke, han anklager Frits for at lyve om sin reaktion på Maries afvisning. I stedet for at forsvare sig mod Bertels anklage indrømmer Frits straks sin løgn: „Forbitret blev jeg, men slog ikke i Bordet«(Stud., p. 311). Men knap har Frits genoptaget sin fortælling, før Bertel igen afbryder ham: „Nu løj du igen, Frits!« (Stud., p. 311). Og endnu engang indrømmer Frits, at han har løjet:

29. En parallel til denne komposition, hvor en præsentation af fortællingens slutning intensiverer og dramatiserer den følgende historie yderligere, findes i Kierkegaards Forførerens Dagbog, hvor vi inden læsningen af Johannes' dagbog kan læse Regines breve skrevet efter forlovelsens ophævelse. 
»Ja, naar I endelig ere saa vantro, at I slet ikke fæste Lid til saa sandsynlige Fiktioner, maa jeg bekende rentud, at jeg følte mig ganske sønderknust og tilintetgjort [...] Jeg ilede til mit Værelse, hvor jeg skrev et afskedsbrev til eder, og styrtede derpaa gennem Havestuen for at udføre mit Forsæt« (Stud., p. 312).

Udtrykket »sandsynlige Fiktioner« indikerer, at sandheden for Frits er mindre vigtig end en god historie, mens sandheden af særligt Bertel prioriteres højere end disse nok »saa sandsynlige Fiktioner«. Med interessen vendt mod det fiktive hellere end mod sandheden illustrerer Frits endnu engang, hvordan iscenesættelsen er i centrum i hans etablering af fortællingen om selvmordsforsøget. Samtidig giver det citerede "at udføre mit Forsæt« indtryk af, at Frits allerede inden Maries afslag har bestemt sig for at iscenesætte sit eget selvmord, hvilket også viser sig at være tilfældet.

På sin vej ud for at udføre sit forsæt møder Frits den tidligere omtalte licentiat. Licentiaten stopper Frits for at veksle et par ord med ham, men i sin iver efter at komme videre skubber Frits til ham, så han falder ind i en glasdør. Og da Frits vågner efter selvmordsforsøget ligger han ved siden af den forskårne licentiat, og beslutter sig for at »opgive Dødstanken for denne Gang« (Stud., p. 313). Frits fortæller i første omgang intet om, hvordan han overlevede selvmordsforsøget, og hvem der skar ham ned. I stedet begynder han en diskussion med studenterne af Maries karakter, hvor han understreger, at hun har "mer Dannelse, end nogen af eder tror» (Stud., p. 316).

Men Frits, "som ved Nydelsen af adskillige Glas Tevandspunsch havde mistet al Gave til at forstille sig«, går efter nogen tid til bekendelse over for studenterne og fortæller dem sandheden om sit selvmordsforsøg. Han forklarer, at han på intet tidspunkt havde intentioner om at tage sit eget liv, men blot ønskede at give Marie en »Straf for sin Grumhed« (Stud., p. 318). Efter at have skubbet licentiaten ind i glasdøren følte Frits sig derfor nogenlunde sikker på, at licentiaten »kunde komme saa meget paa Benene, at han kunne tage mig ned igen«, hvorfor han lod sin »Foldekniv falde paa Jorden ved Roden af Træet« (Stud., p. 319), så han hurtigt kunne blive skåret ned. Med denne indrømmelse ekspliciteres Frits' behov for iscenesættelse ganske betragteligt. Tidligere så vi, hvordan Frits forsøgte at give sin fortælling om selvmordsforsøget et skær af dramatik ved højtideligt at erklære, at han blev skåret ned fra træet »mod min Vilje og mit Vidende«. Og dette forsøg på dramatisering, gennem en bevidst fordrejning af kendsgerningerne, viser, at Frits aldrig har været villig til at gå i døden for Marie: at Marie aldrig vil blive det stabile grundlag, som han søger.

Med den iscenesatte fortælling om sit eget selvmordsforsøg står det klart, at Frits ikke har anset døden som en mulighed for at forenes med noget 
endeligt betegnende, med en endelig signifié. Og at han udelukkende har sat det hele i scene for at give Marie en »Straf for sin Grumhed«, viser endvidere, at hans forelskelse ikke har været helt så dyb og inderlig, som han har givet udtryk for i brevene til studenterne. I samtale med studenterne indrømmer Frits da også, at han »egentlig tilbad et blidere Billede, skabt af min egen Fantasi, til hvilket den strenge Jomfru slet ikke svarede« (Stud., p. 319). Derfor genoptager han sin rejse, denne gang for at opsøge Sophie, der bor tæt på Møllerkroen, mens forelskelsen i Marie affærdiges som en nødvendig del af en historie, der fra starten har været determineret til at ende med en forelskelse i Sophie. Derfor ser Frits straks en parallel mellem sin egen rejse og Odysseus': »Jeg forekommer mig undertiden at ligne den meget udholdende Konge fra Ithaka, som paa Rejsen til Penelope fordrev et Aar med Afrodites gyldne Gærninger hos Kirke« (Stud., p. 320). Dermed begiver Frits sig nu ud på anden del af sin store odyssé efter noget endeligt betegnende.

\section{Mødet med Sophie - endnu en iscenesættelse?}

I tredje kapitel af En dansk Students Eventyr er Frits vendt tilbage til Møllerkroen, hvorfra han håber at kunne komme i kontakt med Sophie. Fra tidligere kun at have hørt om Møllerkroen gennem Frits' breve og fortælling fortælles resten af romanen nu af en alvidende tredjepersonsfortæller uden de tidligere indlagte digressioner og studenternes hyppige diskussioner. Sidste del af den fragmentariske roman besidder derfor ikke de romantiske karakteristika, som har gjort sig gældende i de to foregående kapitler. Endringen i fortælleforhold umuliggør de tidligere digressioner og fortællemæssige labyrinter og betyder samtidig, at de mange skift mellem forskellige genrer nu hører helt op. Dermed ophører også Frits' selviscenesættelse, som den kom til udtryk både i breve og den senere fortælling om selvmordsforsøget til studenterne.

Da Frits ankommer til Møllerkroen er man ved at gøre klar til den store årlige andejagt, hvor han første gang formelt introduceres til Sophie. Men inden mødet med Sophie er Frits ved et tilfælde kommet til at læse licentiatens afhandling om »ulykkelige Skilsmisse mellem Sjæl og Legem« (Stud., p. 332). Frits føler ved læsningen øjeblikkeligt medlidenhed med licentiaten på grund af hans »beklagelsesværdig[e] Sygdom» (Stud., 332f.). Frits glemmer åbenbart et øjeblik, at han som ironiker også selv lider af denne beklagelsesværdige sygdom, da ironien adskiller udtrykket fra indholdet, sjælen fra legemet..$^{30}$ 
Der gives i En dansk Students Eventyr intet entydig svar på, om Frits efter selvmordsforsøget og genforeningen med Sophie overvinder ironien. Men det nævnte skift i fortælleforhold kunne give det indtryk, at han er på rette vej. Med en mere stabil stilistisk udfoldelse, hvor der kun fortælles fra en position og i en enkelt genre, åbnes der for en tolkning, hvor Frits faktisk finder det stabile grundlag, som han hele tiden har forsøgt at overbevise sig selv og studenterne om, at han har fundet. Men selv om muligheden bestemt foreligger, synes det alligevel usandsynligt, at Frits overvinder ironien. Især når man tager romanens videre forløb i betragtning, hvor det viser sig, at Frits hurtigt mister interessen for Sophie.

At Frits hurtigt mister interessen for Sophie er ikke overraskende, da Sophie bl.a. præsenterer et kunstsyn, der må medføre, at Frits ikke kan forene sig med hende. Kort efter deres møde under andejagten fortæller Sophie, at hun finder det "ubegribeligt, hvorledes fornuftige folk, som have Lærdom nok til at give Bøger i Trykken, gide befattet sig med saadanne Narrestreger som Rim» (Stud., p. 343). I stedet for lyrik foretrækker hun »Komedier, hvori der gøres Nar af gamle Mænd«, hvorfor hendes kunstsyn yderligere karikeres. Med dette kunstsyn lægger Sophie afstand til Frits, der ud over at skrive digte også selv er af en sådan lyrisk karakter. Hun vil derfor ikke være i stand til at forstå ham og gennem forståelse hjælpe ham ud af ironien. Alligevel bliver hun i første omgang forblændet af hans frembrusende og pågående adfærd, hvor Frits spiller den form for komedie, som Sophie kan lide, mens han samtidig skjuler den lyriker, han virkelig er. Således illustrerer forelskelsen i Sophie endnu engang, hvordan Frits er en »Kamæleon, der bestandig antager sine Omgivelsers Farver« (Stud., p. 257).

At Frits hurtigt mister interesse for Sophie og samtidig udviser en bevidsthed om, at forelskelsen i hende ikke er oprigtig, bliver tydeligt mod slutningen af romanen, hvor Frits dagen efter ballet på Ravnshøj møder Sophie i haven. Sophie roder sig ud i en længere diskurs om ugudelighed, da hun pludselig bemærker, at Frits ikke hører efter, hvorefter romanen slutter. At Frits, der tidligere har vist en uovertruffen opmærksomhed og pågåenhed over for Sophie, nu pludselig ikke længere hører efter, hvad hun siger, skyldes tydeligvis, at han i sine tanker allerede har forladt hende. Men hvor hans tanker og ønske om at finde stabilitet herefter fører ham hen, afsløres ikke, da romanen slutter umiddelbart efter. En ting synes dog hævet over enhver tvivl: Frits har stadig ikke fundet den endelige signifié, som han har søgt efter hele romanen igennem, og som er den eneste vej ud af ironien.

30. Jvnf. Kierkegaard, der i Om Begrebet Ironi bl.a. taler om en form for ironi, hvor »Phænomenet ikke er Væsenet, men det Modsatte af Væsenet«, O, p. 286. 


\section{Ironi $i$ En dansk Students Eventyr}

Der er, som vi har set, ironi på flere forskellige planer i En dansk Students Eventyr, måske tydeligst i karakteristikken af Frits som en romantisk ironiker. Også i romanens ufærdige karakter, i dens fragmentariske struktur, var det muligt at ane konturerne af en ironi, der selvfølgelig ikke skal tages alt for bogstaveligt, da romanen først blev rekonstrueret og udgivet som fragment efter Poul Møllers død. Men som bekendt er ironiens suspendering af ethvert endeligt tydeligt manifesteret i romanens komposition, herunder både i fortælleforhold og genrevalg, der begge viser en utrolig mangfoldighed. Og hvis man skal tro Vilh. Andersen, var det Poul Møllers oprindelige mening, at romanen skulle præges af endnu flere digressioner, der bl.a. skulle investeres i flere indlagte fortællinger og et enkelt stykke dramatik. ${ }^{31}$

I brevene til studenterne og beretningen om selvmordsforsøget viste Frits et behov for iscenesættelse, der bl.a. skulle tjene til at overbevise studenterne om, at han havde fundet et stabilt grundlag. Men det var ikke kun studenterne, Frits forsøgte at overbevise med sine gentagne iscenesættelser; det var i lige så høj grad sig selv. At Frits gennem iscenesættelserne også forsøgte at overbevise sig selv om, at han havde fundet et stabilt grundlag, medførte, at disse iscenesættelser ikke blot kunne afvises som tilfældige indskydelser. I stedet var iscenesættelserne nødvendige for at Frits kunne bevare illusionen om, at han havde fundet den stabilitet, han søgte. Desværre havde iscenesættelserne også den uheldige effekt, at Frits gennem hver eneste iscenesættelse gav sig mere og mere i ironiens vold og samtidig bevægede sig længere og længere væk fra muligheden af nogen sinde at nå en endelig signifié.

Ifølge Vilh. Andersen, der har forsøgt at rekonstruere romanens videre forløb, drager Frits efter romanens slutning videre ud i verden, hvor han lever »en Tid som Eremit«, inden han efter et par år vender tilbage til Ravnshøj »for at hente sin Brud «. ${ }^{32}$ At Frits virkelig skulle kaste sig ud i et eremitliv for siden at vende tilbage og gifte sig med Sophie, støttes af Billeskov Jansen, der mener, at Frits »kaster sig ud i et vildt Liv, indtil et Gensyn med den kære Pige vækker ham til Besindelse; til sin Sjælebod indleder han da et Eremitliv«. ${ }^{33}$ Vilh. Andersen og Billeskov Jansen ser altså eremitlivet som en

31. Vilh. Andersen: Poul Møller, p. 194ff. Det synes til tider, som om Andersen anser hele Poul Møllers skønlitterære forfatterskab frem til En dansk Students Eventyr - der kan opfattes som afslutningen på Møllers skønlitterære prosaforfatterskab - som en forberedende studie til En dansk Students Eventyr, hvor alt på den ene eller den anden måde skulle have været indskrevet i romanen som endnu en digression

32. Op.cit., p. 380f. Se også Vilh. Andersen: Poul Møller, p. $215 f f$.

33. F.J. Billeskov Jansen: Danmarks Digtekunst, bd. 3, Kbh. 1964, p. 144. 
nødvendig proces, inden Frits kan vende tilbage og gifte sig med Sophie, som han hele tiden har været forelsket i. Skulle Frits vende tilbage og gifte sig med Sophie måtte det indebære, at han havde fundet et fast grundlag, der kunne befri ham for ironien. Ifølge Billeskov Jansen er dette grundlag Sophie, der "vækker ham til Besindelse«, men som den foregående læsning viste, er Sophie bestemt ikke det stabile grundlag, som Frits søger. For da man i romanens slutning følger Frits og Sophies samtale i haven på Ravnshøj, har Frits i tankerne allerede forladt Sophie, hvorfor han må søge sit grundlag et andet sted. Når Vilh. Andersen og Billeskov Jansen forsøger at lægge mønstret fra den romantiske dannelsesroman ned over En dansk Students Eventyr, er det at gøre det foreliggende fragment uret. For Frits finder ikke nogen endelig signifié, hvorfor han må fortsætte sin søgen efter en stabilitet, der kan befri ham fra ironiens fængsel. ${ }^{34}$

\section{Professoren og studenten}

Som vi tidligere har set, indtog Poul Møller i »Om Begrebet Ironie« et moralsk standpunkt i sin afvisning af ironi, da brugen af ironi nødvendigvis må »ende med Savn af alt Indhold« (»OBI«, p. 156). Senere, i anmeldelsen af Gyllembourgs Ekstremerne, blev denne kritik tydeliggjort, da Poul Møller skrev, at en kunstner, der har bragt det til en "fuldkommen Ironi [...] er ikke nogen ægte Kunstner. ${ }^{35}$ Derfor må den sande kunstner »først og fremmest være et sandt Menneske«, som ikke lader sig lokke af »Ironiens Frihed. ${ }^{36}$ Flere af disse tanker lod sig også genfinde i Kierkegaards senere Om Begrebet Ironi.

At Poul Møller selv har ladet sig lokke af »Ironiens Frihed«, viste sig i læsningen af En dansk Students Eventyr. Ironien manifesterede sig her på flere forskellige niveauer. Denne diskrepans mellem afvisningen af ironi i de æstetiske skrifter og anvendelsen af den i de skønlitterære kan ifølge Vilh. Andersen forklares biografisk, da En dansk Students Eventyr hører til blandt Poul Møllers ungdomsværker, hvorfor kritikken i »Om Begrebet Ironie«»fremtræder som Professorens Kritik af Studentens Filosofi.« ${ }^{37}$

34. En interessant parallel til En dansk Students Eventyr er Kierkegaards Gjentagelsen, 1843, hvor Kierkegaard i fremstillingen af det unge menneske uden tvivl har kigget Poul Møller over skulderen. Gjentagelsens gæld til En dansk Students Eventyr viser sig også i romanens vekslen mellem iscenesatte breve og fortællende prosa. Men ironien i Gjentagelsen får et ekstra niveau, da det viser sig, at Constantin Constantius selv har opfundet og digtet det unge menneske, mens Constantin Constantius selv er opfundet og digtet af Kierkegaard.

35. Poul Møller: »Recension af »Ekstremerne«", p. $147 \mathrm{f}$.

36. Op.cit., p. 147, og "Tanker over Muligheden af Beviser for Menneskets Udødelighed», op.cit., p. 180. 
Vilh. Andersens synspunkt er ganske forståeligt, når man ser kritikken i "Om Begrebet Ironie« og andre af Møllers sene, æstetiske skrifter i forhold til den ironiske udfoldelse i En dansk Students Eventyr. Spørgsmålet er dog om sandheden ikke er mere kompliceret: om ikke Møller allerede i En dansk Students Eventyr foregriber denne kritik ved at portrættere Frits' uopnåelige længsel efter en stabilitet, der kan befri han fra ironiens fængsel. Men også at Møller kender ironien og dens faldgruber indefra: at fremstilling af ironi som i En dansk Students Eventyr - om end sigtet måske nok er polemisk - indebærer en brug af ironi, der ikke sådan lader sig styre, da ironien altid, som Kierkegaard påpegede, er »blot en Allegori, der skjuler et høiere Ideal i sig, og saaledes i det Uendelige«. Dette er måske også en af grundene til, at Poul Møller, trods et moralsk standpunkt, ikke er nær så uforsonlig i sin afvisning af ironien som Kierkegaard. I hvert fald viser læsningen af En dansk Students Eventyr, at romanen er meget mere end blot en studenterroman, der viser konturerne af den stærke tradition med dannelsesromanen. I stedet har vi set spor af en kompleks og gennemtænkt roman, der både i komposition og tematik har fingeren på pulsen i datidens romantisk, filosofiske debat. En debat der i dag synes lige så aktuel som nogensinde.

37. Vilh. Andersen: Poul Møller, p. 340. 